\title{
Evaluasi Program Pendidikan Pemakai Dengan Model CIPP di Perpustakaan Fakultas Teknik UGM
}

\author{
${ }^{1}$ Nova Indah Wijayanti, ${ }^{2}$ Rita Yulianti, ${ }^{3}$ Bagus Wijaya \\ Universitas Gadjah Mada \\ 1e-mail: nova_indah@ugm.ac.id \\ 2 e-mail: rita.yulianti@ugm.ac.id \\ 3 e-mail: bagus_wijaya@ugm.ac.id
}

\begin{abstract}
The optimal use of libraries is through user education, because through this program users get a series of knowledge about information sources. One way to find out the success of a program is to do an assessment. This study aims to evaluate the implementation of user education that has been implemented in the Library of the Faculty of Engineering UGM. CIPP Model (Context, Input, Process \& Product) used for evalution with a qualitative approach. Research subjects were members of the UGM Faculty of Engineering who had attended user education programs and library management team. Data collection is done with documentation, interviews, and observations. The results showed (1) the Context evaluation was good, there was a match between the program with the vision and mission of the institution, (2) Evaluation of inputs was good, supporting facilities and facilities were adequate, (3) Process evaluation was sufficient, the implementation schedule needed to be improved, (4) Evaluation of the product is good, there is a certificate as a sign of following the activity by achieving the competency that has been set. The factors that support the implementation of the program are competency of human resources, communication, adequate facilities and infrastructure, and good cooperation with stakeholders. The factors that hinder the program are the schedule of activities that are not yet routine, those responsible for the program cannot be delegated to other people, there is no analysis of student needs, and there is no written policy on this program. The recommendation of this research is that it is necessary to improve several inhibiting factors so that the implementation of user education activities can run smoothly in accordance with the stated goals.
\end{abstract}

Keywords: User Education; CIPP; Evaluation; Library

\section{Abstrak}

Pemanfaatan perpustakaan secara optimal adalah melalui pendidikan pemakai, karena melalui program ini pemustaka mendapatkan serangkaian 
pengetahuan mengenai sumber-sumber informasi. Salah satu cara untuk mengetahui keberhasilan suatu program adalah dengan melakukan asesmen. Penelitian ini untuk bertujuan untuk mengevaluasi implementasi pendidikan pemakai yang telah dilaksanakan di Perpustakaan Fakultas Teknik UGM. Model evaluasi yang digunakan adalah CIPP (Context, Input, Process \& Product) dengan pendekatan kualitatif. Subyek penelitian adalah anggota Perpustakaan Fakultas Teknik UGM yang telah mengikuti program pendidikan pemakai dan tim manajemen perpustakaan. Pengumpulan data dilakukan dengan dokumentasi, wawancara, dan observasi. Hasil penelitian menunjukkan (1) Evaluasi Context sudah baik, ada kesesuaian antara program dengan visi dan misi institusi, (2) Evaluasi input sudah baik, faktor sarana dan prasara pendukung yang memadai, (3) Evaluasi process cukup, perlu diperbaiki jadwal pelaksanaan, (4) Evaluasi product sudah baik, ada pemberian sertifikat sebagai tanda mengikuti kegiatan dengan mencapai kompetensi yang telah ditetapkan. Faktor-faktor yang mendukung pelaksanaan program adalah kompetensi SDM, komunikasi, sarana dan prasana yang memadai, dan kerjasama yang baik dengan stakeholder. Faktorfaktor yang menghambat program adalah jadwal kegiatan yang belum rutin, penanggung jawab program belum bisa didelegasikan kepada orang lain, belum ada analisis kebutuhan mahasiswa, dan belum ada kebijakan tertulis tentang program ini. Rekomendasi dari penelitian ini adalah perlu diperbaiki beberapa factor penghambat agar pelaksanaan kegiatan pendidikan pemakai bisa berjalan lancer sesuai dengan tujuan yang telah ditetapkan.

Kata Kunci: Pendidikan Pemakai; CIPP; Perpustakaan; Evaluasi

\section{A. PENDAHULUAN}

Salah satu faktor keberhasilan kegiatan belajar mengajar di Perguruan Tinggi adalah keaktifan mahasiswa untuk belajar secara mandiri. Upaya untuk belajar mandiri dapat dilakukan dengan memanfaatkan secara optimal sumber-sumber informasi yang ada di Perpustakaa Perpustakaan merupakan salah satu diantara sarana dan sumber belajar yang efektif untuk menambah pengetahuan, yang dapat dipelajari secara individual oleh pemakainya. Pemanfaatan perpustakaan di Perguruan Tinggi sangat erat kaitannya dengan proses belajar mengajarnya. Hal ini karena pola pengajaran pada era keterbukaan informasi ini adalah untuk memperoleh sebanyak-sebanyaknya ilmu pengetahuan yang dapat terlaksana jika mahasiswa dapat memanfaatkan perpustakaan. Dengan prinsip ini, maka para mahasiswa diharapkan memiliki jiwa long life learning menguasai hard skill dan soft skill yang saling mendukung (Harsono, 2008) 
Proses belajar yang menuntut keaktifan mahasiswa berakibat adanya tuntutan ketersediaan sumber belajar yang efektif dan efisien. Sumber belajar yang ada, dikembangkan untuk memudahkan proses pembelajaran. Sumber daya pembelajaran seperti ketersediaan ruang, ruang baca (perpustakaan), alat bantu pembelajaran dan teknologi informasi harus dapat diakses dengan mudah oleh dosen dan mahasiswa. Hal ini menegaskan bahwa perpustakaan sebagai sarana pembelajaran perlu dikembangkan agar dapat menjalankan fungsinya sebagai pusat sumber belajar dengan kebutuhan mahasiswa.

Hasil penelitian dari Crazer \& Sprezi (2012) dalam Klain-Gabbay (Klain-Gabbay and Shoham, 2016) menunjukkan bahwa kebanyakan permintaan pemustaka terhadap layanan perpustakaan adalah memberikan akses yang maksimal terhadap sumber-sumber informasi online daripada bahan tercetak (in printed material). Hal ini terlihat dari tren perubahan layanan perpustakaan yang tadinya hanya bersifat peminjaman dan pengembalian buku, berkembang menjadi layanan user training program seperti pelatihan pencarian informasi digital, pelatihan akses jurnal online, diskusi-diskusi ilmiah dan lain sebagainya. Tren perubahan layanan tersebut terlihat dalam gambar berikut ini:

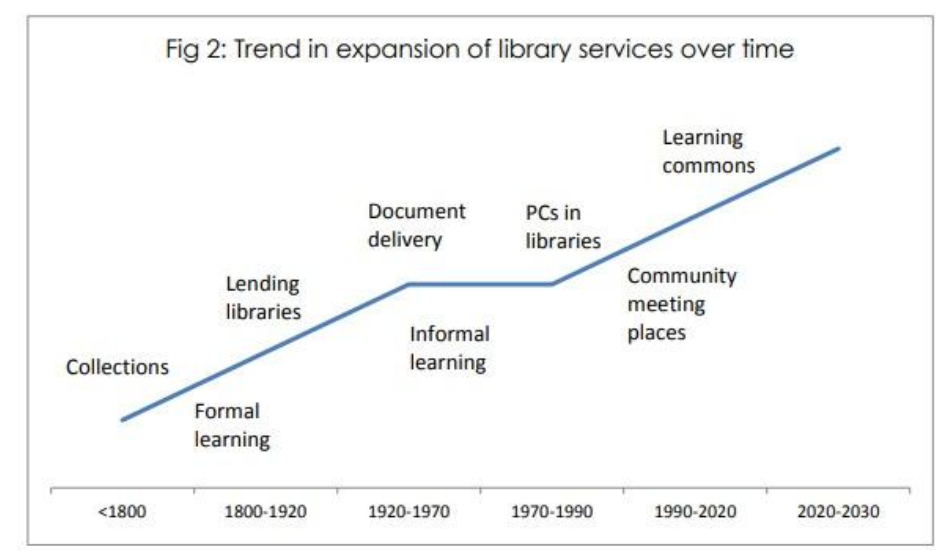

Gambar 1. Tren Pengembangan Layanan Perpustakaaan (Sumber: Australian Library Association, 2012)

Gambar di atas menunjukkan terdapat perubahan tren layanan perpustakaan. Perubahan perilaku ini salah satunya adalah dampak kemajuan teknologi dan informasi. Perpustakaan yang tadinya berfungsi sebagai "penjaga informasi" berkembang perannya untuk menyebarluaskan informasi dan publikasi. Perpustakaan tidak hanya menyediakan bahan pustaka dan menjadi tempat baca, tetapi menjadi learning common dengan berbagai fasilitas yang disediakan. Hal ini menjadi tantangan bagi perpustakaan untuk 
memberikan layanan dengan mempertimbangkan kebutuhan pemustaka. Konsep Student Center Learning (SCL) yaitu mahasiswa sebagai pusat pembelajaran maka konsep dari pendidikan pemakai adalah sesuai dengan karakteristik pemustaka.

Pemanfaatan perpustakaan secara optimal adalah melalui pendidikan pemakai, karena melalui program ini pemustaka mendapatkan serangkaian pengetahuan mengenai sumber-sumber informasi. Salah satu cara untuk mengetahui keberhasilan suatu program adalah dengan melakukan asesmen terhadap suatu program. Hal ini penting karena Perpustakaan merupakan organisasi tempat menyimpan aset pengetahuan dan kekayaan intelektual sebuah institusi. Evaluasi diperlukan agar program yang dijalankan bisa diketahui dampak dan tingkat keberhasilannya, dalam hal ini adalah program pendidikan pemakai di perpustakaan. Evaluasi juga bermanfaat untuk memberikan arah dan metode dalam meningkatkan pelayanan dan sumber daya yang dimiliki (Lewin and Passonneau 2012). Untuk itulah kami tertarik untuk meneliti implementasi program pendidikan pemakai yang dilaksanakan di Perpustakaan Fakultas Teknik UGM dengan metode penelitian evaluasi. Hasil penelitian diharapkan diketahui tingkat keberhasilan program dan faktor-faktor penghambat program sehingga bisa memberikan rekomendasi kepada institusi berdasarkan hasil penelitian.

Perumusan masalah berdasarkan paparan di atas adalah : Bagaimana implementasi pendidikan pemakai di Perpustakaan Fakultas Teknik UGM. Apakah faktor-faktor pendukung keberhasilan pendidikan pemakai di Perpustakaan Fakultas Teknik UGM. Apakah faktor-faktor penghambat keberhasilan pendidikan pemakai di Perpustakaan Fakultas Teknik UGM. Penelitian ini bertujuan untuk Mengetahui hasil evaluasi pendidikan pemakai di Perpustakaan Fakultas Teknik UGM DAN mengetahui faktor-faktor pendukung dan penghambat keberhasilan pendidikan pemakai di Perpustakaan Fakultas Teknik UGM.

Beberapa penelitian terdahulu terkait pendidikan pemakai perpustakaan telah dilakukan oleh peneliti lain. Penelitian yang dijadikan dalam rujukan penelitian ini adalah lanjutan dari penelitian Tawaf (Tawaf, 2007) dengan subjek dan model yang berbeda. Letak perbedaannya adalah pada penggunaan metode penelitian, Tawaf menggunakan pendekatan kuantitatif sedangkan penelitian ini menggunakan pendekatan kualitatif dengan model Context, Inpur, Process and Product (CIPP). 


\section{Teori Pembelajaran}

Teori pembelajaran ada 4 macam yaitu: behaviorist learning, cognitive learning dan humanis approach (Harker 2009). Penjabaran dari teori pembelaran ini adalah sebagai berikut Behaviourist learning, yaitu guru/Tutor menjadi pusat pembelajaran. Guru memberikan rancangan dan stimulan untuk mencapai pola perilaku yang diinginkan. Pembelajaran dilakukan dengan mengulangi langkah demi langkah untuk mencapai tujuan. Penerapan dalam perpustakaan, proses belajar ini ada banyak contoh misalnya melakukan pencarian informasi di database, mengakses dan menggunakan katalog perpustakaan dengan diajari dan ditunjukkan bagaimana prosesnya, kemudian peserta diminta untuk mengulangi dan mengikuti tindakan yang dicontohkan. Proses ini diulang sampai peserta yakin untuk mendapatkan hasil sesuai yang dicontohkan. Cognitive learning yaitu teori belajar ini memungkinkan peserta mengembangkan tentang subyek yang mereka pelajari. Jadi mereka tidak mencontoh persis yang diberikan oleh guru/tutor tetapi berpartisipasi secara aktif untuk memahami yang yang sedang dipelajari, kemudian menerapkan kembali. Model ini sangat sesuai untuk dilakukan di perpustakaan. Peserta tidak cukup hanya mendengarkan instruksi dari tutor untuk pencarian informasi di database misalnya, tetapi perlu mempraktikkan dan mengalami sendiri pencarian informasi tersebut dengan cara mereka sendiri berdasarkan ingatan dari instruksi dari tutor. Hal ini lebih efektif untuk meningkatkan keterampilan peserta. Humanist Approach yaitu aktivitas merupakan elemen kunci dari proses pembelajaran, tetapi mendapatkan pengalaman terbaik selama mengikuti training adalah suatu hal yang penting. Hal ini dapat dicapai apabila peserta training menjadi pusat pembelajaran dengan pendekatan yang humanis (humanis approach). Peserta mengendalikan dan mengontrol apa dan bagaimana mereka belajar, memilih yang paling mereka pahami dan kemudian mengembangkan sesuai dengan pilihan mereka.

Strategi pembelajaran untuk pendidikan pemakai perpustakaan merupakan rencana untuk mencapai tujuan, langkah-langkah yang bisa diterapkan adalah sebagai berikut: Pendahuluan, pustakawan melakukan observasi dan persiapan sebelum melakukan kegiatan pendidikan pemakai, kemudian dituangkan dalam rencana kerja. Penyampaian informasi yaitu pelaksanaan kegiatan pendidikan pemakai mengikuti alur rencana kerja yang telah ditetapkan dengan sistematis sehingga pemustaka memahami informasi yang disampaikan dan tujuan pemanfaatan perpustakaan bisa tercapai. Partisipasi pemustaka yaitu pemustaka diajak secara aktif melakukan latihanlatihan secara langsung, praktik dengan bahan ajar yang telah disiapkan 
untuk ketrampilan pencarian informasi. Metode pembelajaran adalah praktik pembelajaran, cara yang digunakan untuk mencapai tujuan yang telah diterapkan, bersifat prosedural dan implementatif (Siregar, 2014).

\section{Pendidikan Pemakai}

Pendidikan pemakai (user education) di perpustakaan perguruan tinggi menjadi 3 level yaitu: Level pertama atau level dasar untuk mahasiswa baru, diberikan pengenalan perpustakaan dapat diaplikasikan untuk mereka yang pertama kali memanfaatkan perpustakaan. Level kedua, diberikan pada mahasiswa sesuai dengan jurusan masing-masing. Level ketiga, literature search training, adalah pemberian pendidikan pemakai dengan lebih menekankan pada praktek pencarian literatur untuk penelitian, hal ini tepat untuk persiapan tugas akhir/penelitian (Chen and Lin 2011).

Merujuk pendapat Chen tersebut di atas, bisa disimpulkan bahwa perpustakaan dapat mengaplikasikan proram pendidikan pemakai sesuai dengan jenjang level mahasiswa. Oleh karena itu implementasi pendidikan pemakai di perpustakaan perguruan tinggi merupakan hasil kolaborasi antara pustakawan, staf akademik, bagian teknologi informasi dan mahasiswa agar bisa tepat sasaran.

Pendidikan pemakai merupakan salah satu program yang diterapkan untuk pemanfaatan perpustakaan. Tahapan dalam pendidikan pemakai perpustakaan (user education) adalah : Pengenalan perpustakaan adalah sebuah tahapan dasar/basic pengenalan Perpustakaan ke pemustaka yang dilakukan saat awal semester baru bersamaan dengan Program Orientasi Kampus. tahap selanjutnya yaitu instruksi bibliografi, pemustaka diberi pengetahuan dasar mengenai buku dan bagian-bagian dari buku seperti indeks, abstrak dan manfaatnya untuk keperluan referensi mereka. Keterampilan pencarian informasi, pemustaka diberi pengetahuan tentang ketrampilan belajar mandiri dan kemampuan berkomunikasi. Hal ini bermanfaat untuk diterapkan kebutuhan mereka seperti mencatat, membaca, mencari literatur, menulis essay, dan menulis kutipan bibliografi. Instruksi online, Pemustaka diberi pengetahuan tentang pencarian informasi secara online. Metode instruksional, metode Pendidikan Pemakai yang dipilih disesuaikan dengan jumlah mahasiswa, anggaran, kemampuan pustakawan, waktu dan subyek yang dipilih (Downard, 1992)

Merujuk dari tahapan dalam pendidikan pemakai tersebut di atas, pendidikan pemakai adalah serangkaian program yang diterapkan di perpustakaan dengan tujuan pengenalan perpustakaan untuk mendukung 
keberhasilan belajar dari pemustaka. Artinya, setiap perpustakaan bisa membuat program pendidikan pemakai yang paling efektif untuk diterapkan sesuai dengan karakteristik pemustaka dan kompetensi pustakawan. Di Perpustakaan Fakultas Teknik UGM, pendidikan pemakai yang dilaksanakan adalah berbentuk training dan diskusi dengan pakar. Untuk mengetahui tercapainya pendidikan pemakai maka akan diteliti 3 (tiga) aspek yaitu: (1) Pengenalan/sosialisasi program (2). Pelaksanaan program (3) Proses asesmen training.

\section{Student Center Learning}

Metode belajar yang inovatif adalah metode belajar yang berpusat pada mahasiswa (Student Centered Learning) yang memiliki keragaman model pembelajaran yang menuntut partisipasi aktif mahasiswa. Metodemetode tersebut adalah: (1) Information sharing (berbagi informasi) dengan cara curah gagas, kooperatif, kolaborasi, diskusi kelompok, diskusi panel, simposium dan seminar, (2) Experienced based (belajar dari pengalaman) dengan cara simulasi, bermain peran, permainan dan kelompok temu, (3) Problem Solve Based (Pemecahan masalah) dengan cara studi kasus, tutorial dan lokakarya. Secara operasional, di dalam SCL mahasiswa memiliki keleluasaan untuk mengembangkan segenap potensinya, mengeksplorasi bidang ilmu yang diminati, membangun pengetahuan, serta mencapai kompetensinya melalui proses pembelajaran aktif, interaktif, kolaboratif, kontekstual dan mandiri.

\section{Layanan Perpustakaan}

Layanan perpustakaan adalah pemberian dan penyediaan informasi kepada pemustaka. Secara lebih luas tugas layanan perpustakaan adalah memberikan pelayanan dan bimbingan agar para pemustaka dapat memanfaatkan fasilitas perpustakaan untuk dapat memperoleh informasi yang dibutuhkan. Tujuan layanan perpustakaan adalah memberikan kesempatan seluas-luasnya bagi seluruh masysrakat untuk memperoleh informasi dan melakukan pembelajaran seumur hidup (long life learning). Perpustakaan tidak hanya menyediakan bahan pustaka dan menjadi tempat baca tetapi menjadi learning common dengan berbagai fasilitas yang disediakan. Peran lebih luas adalah melalui perpustakaan, penelitian dan penulisan ilmiah dibuat, dievaluasi dan dilestarikan untuk digunakan di masa mendatang. 


\section{Evaluasi Program}

Evaluasi program adalah suatu kegiatan yang dilakukan untuk mengetahui keberhasilan pelaksanaan program (Arikunto, 1993). Kegiatan ini dilakukan dengan tujuan untuk mengetahui tingkat keberhasilan program. Model-model evaluasi program menurut Arikunto dkk. Ada 8 (delapan) macam yaitu: Goal Oriented Evaluation Model, Goal Free Evaluation Model, Formatif Summatif Evaluation Model, Countenance Evaluation Model, Responsif Evaluation Model, CSE-UCLA Evaluation Model, Discrepancy Model dan CIPP Evaluation Model.

Definisi dari masing-masing model evaluasi adalah: 1) Goal Oriented Evaluation Model adalah model evaluasi yang bertujuan untuk mengetahui tujuan kegiatan dan berlangsung dengan terus berkesinambungan. Indikator keberhasilan program dilakukan dengan sejauh mana tujuan kegiatan tersebut telah tercapai. 2) Goal Free Evaluation Model tidak memperhatikan tujuan program tetapi mengevaluasi pelaksanaan program dan mendokumentasikan kejadian positif maupun negatif selama pelaksanaan program. 3) Formatif Summatif Evaluation Model adalah evaluasi saat program berjalan (formatif) dan ketika program sudah selesai (summatif). Evaluasi ini bertujuan untuk mengetahui seberapa tingkat keberhasilan program dan kesesuaian dengan tujuan. 4) Countenance Evaluation Model model ini menekankan pada penilai agar membuat keputusan/penilaian terhadap program yang sedang berjalan dilakukan dengan benar. Evaluasi meliputi 3 (tiga) tahap yaitu persiapan, proses dan keluaran. 5) Responsif Evaluation Model adalah evaluasi yang menekankan pada respon klien. Indikator dari evaluasi ini adalah berorientasi langsung pada aktivitas program, memberikan respon pada kebutuhan informasi dari audien, dan perspektif nilai dari orang-orang yang dilayani. 6) CSE-UCLA Evaluation Model adalah singkatan dari Center for the Study of Evaluation, UCLA adalah singkatan dari University of California Los Angeles. Evaluasi ini meliputi 5 tahap yaitu perencanaan, pengembangan, implementasi, hasil dan dampak. 7) Discrepancy Model adalah evaluasi kesenjangan program. Evaluasi ini bertujuan untuk mengetahui tingkat kesesuaian antara standar yang ditetapkan dengan pelaksanaan program. 8) CIPP Evaluation Model adalah evaluasi model pengambilan keputusan. CIPP adalah singkatan dari Context, Input, Process dan Product.

Pemilihan model evaluasi yang akan digunakan disesuaikan dengan tujuan evaluasi. Penelitian ini bertujuan untuk memberikan penilaian terhadap program pendidikan pemakai yang dilaksanakan untuk memberikan rekomendasi kepada Perpustakaan Fakultas Teknik UGM dalam mengambil 
keputusan pelaksanaan program. Sesuai dngan tujuan evaluasi tersebut, maka kami memilih model Evaluasi CIPP yang lengkap dan komprehensif sesuai dengan tahapan evaluasi.

\section{Evaluasi CIPP}

CIPP merupakan singkatan dari context, input, process dan product. Evaluasi model ini memiliki tujuan untuk memperbaiki program. Orientasi dari evaluasi ini adalah sebagai bahan pertimbangan untuk membuat keputusan dari decicion maker (pemegang keputusan). Evaluasi model CIPP bisa diterapkan dalam berbagai bidang yaitu pendidikan, manajemen, perusahaan dalam bentuk proyek, program maupun institusi. Model evaluasi dari sebuah program yang dianggap sebagai suatu sistem, sehingga dalam menganalisis program berdasarkan komponen-komponennya yaitu Context, Input, Process dan Product, 1) Evaluasi context, pelaksanaan pendidikan pemakai bertujuan untuk pengenalan perpustakaan, pemanfaatan perpustakaan dan peningkatan literasi informasi. Sehingga context yang dimaksud di sini adalah kondisi lingkungan yang mendukung pelaksanaan program ini. 2) Evaluasi input pendidikan pemakai perpustakaan adalah kondisi penunjang pelaksanaan program tersebut yang meliputi proses pendaftaran ,sarana dan prasarana, kolaborasi dengan pihak lain. 3) Evaluasi process adalah kajian efektivitas pelaksanaan program pendidikan pemakai. 4) Evaluasi product adalah dampak dari pelaksanaan program pendidikan pemakai. Evaluasi produk berupa hasil dari mengikuti program ini, baik berupa peningkatan pemahaman maupun berupa sertifikat sebagai tanda telah mengikuti program dengan baik.

Konsep CIPP meliputi 4 (empat) hal yaitu Contex adalah sebagai gambaran dan spesifikasi terhadap lingkungan program, kebutuhan yang belum terpenuhi, karakteristik populasi dari individu program tersebut. Hasil dari evaluasi konteks adalah memberikan beberapa alternatif keputusan yaitu: setting yang akan diterapkan, tujuan dan sasaran yang adakan dicapai. Evaluasi input memberikan informasi tentang mengatur keputusan, menentukan sumber-sumber yang ada, alternatif yang diambil dan strategi apa untuk mencapai tujuan. Komponen dalam evalusi input yaitu: sumebr daya manusia, sarana dan peralatan pendukung, anggaran dan prosedur atau aturan yang diperlukan Process. Evaluasi ini berguna untuk mendeteksi rancangan program selama tahap implementasi, menyediakan informasi keputusan program dan sebagai arsip proses yang telah terjadi. Evaluasi proses memberikan manfaat untuk mengetahui pelaksanaan program sudah sesuai dengan rencana atau belum dan hal apa saja yang perlu diperbaiki. 
Jadi, evaluasi process merupakan pelaksanaan kegiatan nyata di lapangan. Evaluasi product merupakan penilaian keberhasilan suatu kegiatan yang telah direncanakan dengan tujuan yang telah ditetapkan. Hasil dari evaluasi bertujuan untuk menentukan program akan diteruskan atau tidak.

\section{Metode Penelitian}

Jenis penelitian ini penelitian evaluasi dengan pendekatan kualitatif. Penelitian evaluasi adalah penelitian penerapan prosedur ilmiah yang sistematis untuk menilai implementasi, rancangan dan efektivitas suatu program. Model evaluasi yang dipilih adalah CIPP yaitu singkatan dari Context evaluation, Input Evaluation, Process evaluation, and Product evaluation. Jadi CIPP merupakan metode evaluasi yang memandang program yang dievaluasi sebagai suatu sistem.

Penjabaran tentang evaluasi program pendidikan pemakai dengan model CIPP tersebut di atas, maka berikut ini adalah desain penelitian yang akan dilakukan:

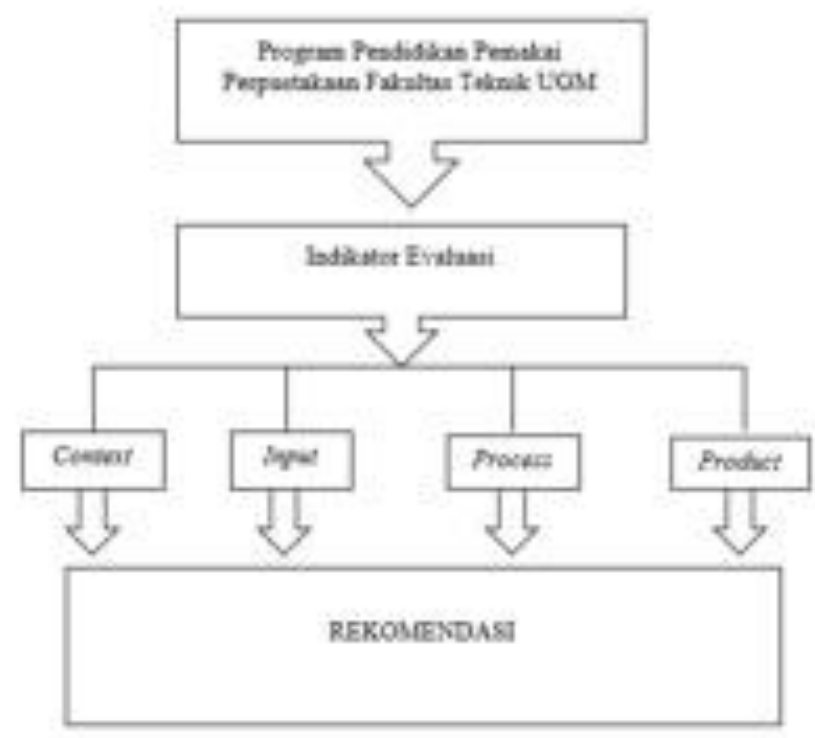

Gambar 2. Desain penelitian pengembangan model CIPP

Pengumpulan data dalam penelitian ini adalah 1) observasi, mengamati proses yang terjadi selama proses penelitian melalui metode ini diharapkan dapat memperoleh hasil penelitian yang lebih lengkap. 2) 
Wawancara, teknik ini digunakan untuk mendapatkan gambaran yang utuh dan hasil yang valid tentang implementasi program. Wawancara dilakukan terhadap pihak-pihak terkait yang terlibat dalam program ini baik internal maupun eksternal. 3) Dokumentasi, yaitu dokumen dan informasi tertulis tentang pelaksanaan pendidikan pemakai.

Subyek dari penelitian ini adalah sumber data dan informasi berupa orang, sumber dokumentasi dan data tertulis lainnya. Subyek penelitian ini adalah pelaksana program pendidikan pemakai perpustakaan Fakultas Teknik UGM yang terdiri dari Kepala Perpustakaan, Pustakawan, staf administrasi dan mahasiswa yang mengikuti program tersebut, yaitu 3 (tiga) dari internal (tim manajemen perpustakaan) dan 9 dari eksternal yaitu mahasiswa peserta pendidikan pemakai, jadi total informan dalam penelitian ini ada 13 orang.

Analisis data dalam penelitian kualitatif memiliki dua tujuan yaitu: (1) menganalisis proses berlangsungnya suatu fenomena sosial dan memperoleh gambaran tuntas dari proses tersebut (2) menganalisis makna yang ada dibalik informasi, data dan proses suatu fenomena sosial. Untuk itu analisis data yang digunakan dalam penelitian ini adalah model Miles and Huberman (Sugiyono, 2008)yang tergambar dalam diagram berikut ini:

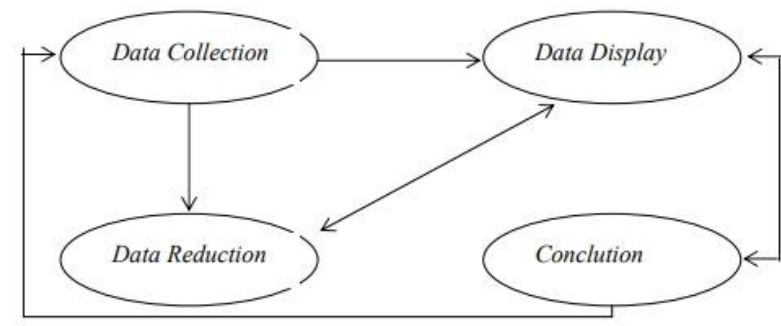

Gambar 3. Skema Analisis Data

Konsep validitas dalam penelitian kualitatif adalah kredibilitas. Keberhasilan pada penelitian kualitatif adalah berhasil mengeksplorasi masalah atau mendeskripsikan seting, proses, kelompok sosial atau pola interaksi yang majemuk. Kredibilitas yang tinggi juga dicapai jika partisipan yang terlibat dalam penelitian mengenali informasinya. Konfirmasi dan klarifikasi data diperoleh dengan dua cara yaitu: 1) Member check, mendatangi kembali partisipan atau responden pada proses analisis data. 2) Peer checking diskusi dengan ahli untuk melakukan reanalisis data yang diperoleh. 
Pengujian dilakukan oleh Ag. Dicky Prastomo, SIP.,MA sebagai Dosen Ilmu Komunikasi pada Universitas Soegijopranoto Semarang yang menguasai bidang evaluasi Program.

Hasil uji validitas tersebut di atas, berdasarkan persentase rentang nilai termasuk baik dan sangat baik. Rerata nilai uji validitas adalah $86 \%$. Hal ini menunjukkan bahwa instrument yang digunakan cukup memenuhi syarat untuk meneliti program pendidikan pemakai dengan model CIPP. Saran dari ahli adalah perlu mensinergikan lingkungan stakeholder khususnya pendidikan pemakai di Perpustakaan Fakultas Teknik UGM dengan mengkombinasi unsur pelayanan/service (nilai guna/value in Use) dan Produk (nilai tukar/Value in exchange).

\section{B. HASIL DAN PEMBAHASAN}

Manajemen Perpustakaan FT UGM membuat zonasi ruang untuk memudahkan pemanfaatan ruang. Zonasi ruang adalah sebagai berikut: 1) Zona hijau adalah zona ruangan yang diperbolehkan untuk belajar dan diskusi dengan suara kecil/ringan dan tidak mengganggu. Ruanan ada di Lantai 1 dan Lantai 2 Ruang diskusi. 2) Zona merah adalah ruang untuk belajar mandiri, tidak berkelompok, tidak diperbolehkan mengganggu

Perpustakaan FT UGM memiliki 7 orang karyawan dengan tugas masing-masing. Strustur organisasi Manajemen perpustakaan sesuai informasi dari website perpustakaan http://lib.ft.ugm.ac.id adalah:

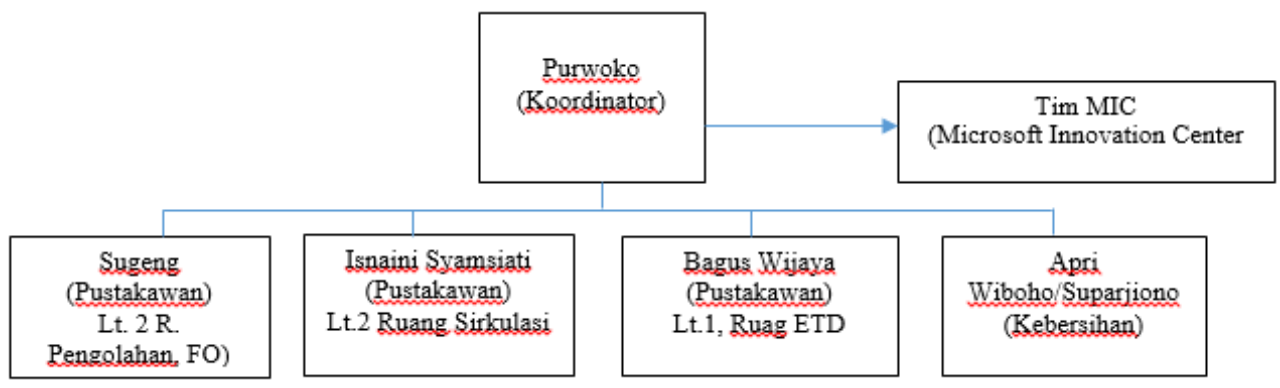

Gambar 4. Struktur Organisasi Manajemen Perpustakaan FT UGM

Perpustakaan Fakultas Teknik UGM memiliki beberapa program pendidikan pemakai berupa training/pelatihan dan pembelajaran dengan metode diskusi dengan pakar yang telah terlaksana sejak tahun 2015. Program ini digagas oleh Kepala Perpustakaan Fakultas Teknik UGM dengan mempertimbangkan kebutuhan pemustaka.

Data pelatihan untuk pemakai di Perpsutakaan FT UGM adalah: 
Tabel 1. Data Pelatihan untuk Pemakai di Perpustakaan FT UGM

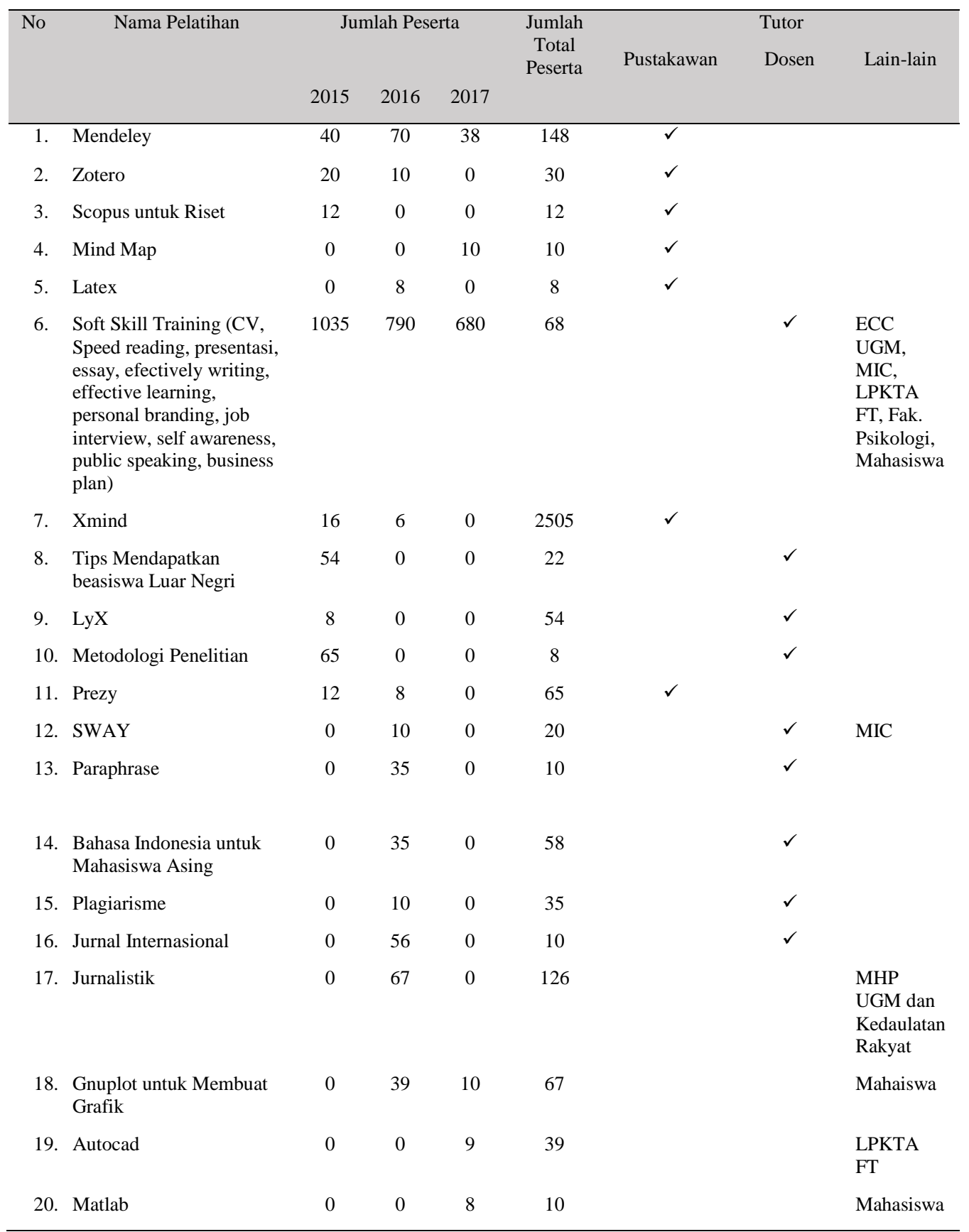

Sumber: data primer diolah

Responden untuk penelitian ini ada 12 orang, 30\% dari responden berasal dari luar institusi Fakultas Teknik UGM dan 70\% sisanya berasal 
dari Fakultas Teknik UGM. Ada dua macam responden yaitu tim manajemen perpustakaan dan peserta pendidikan pemakai.

\section{Evaluasi CIPP}

\section{Evaluasi Context}

Evaluasi Context dalam progam pendidikan pemakai di Perpustakaan FT UGM meliputi letak dan kondisi perpustakaan yang merupakan perpustakaan Fakultas. Data untuk evaluasi context diperoleh dari Tim Manajemen Perpustakaan dan dokumen pendukung. Pemahaman tentang kondisi lingkungan penting, untuk menganalisis faktor-faktor pendukung program ini bisa terlaksana. Fakultas Teknik UGM terdiri beberapa Departemen yaitu: Departemen Teknik Arsitektur dan Perencanaan, Departemen Teknik Elektro dan Teknologi Informasi, Departemen Teknik Nuklir dan Teknik Fisika, Departemen Teknik Geodesi, Departemen Teknik Geologi, Departemen Teknik Kimia, Departemen Teknik Mesin dan Industri dan Departemen Teknik Sipil dan Lingkungan.

Departemen tersebut memiliki perpustakaan sendiri yang pengelolaannya mandiri untuk pengadaan koleksi dan sirkulasi (peminjaman dan pengembalian buku). Adapun pendidikan pemakai dipusatkan di perpustakaan Fakultas. Evaluasi ini penting karena menyangkut strategi apa yang sudah dilakukan oleh perpustakaan dan stakeholder untuk mewujudkan program ini.

a. Kebijakan program

Hasil observasi, kebijakan program pendidikan pemakai tidak ada kebijakan tertulis atau Surat Keputusan untuk program tersebut. Artinya, mahasiswa tidak diwajibkan untuk mengikuti program tetapi lebih bersifat himbauan. Tujuan program ini diadakan adalah: agar mahasiswa menguasai materi yang ada agar dapat bermanfaat dalam proses akademik selama kuliah di Perpustakaan FT UGM, membantu mahasiswa memperoleh ketrampilan dalam belajar saat menyusun tugas akhir dan membuat tulisan-tulisan ilmiah dan memberikan keterampilan softskill pada mahasiswa Fakultas Teknik UGM. Analisis kebutuhan program ini dilakukan dengan pengamatan dan wawancara dengan beberapa mahasiswa, artinya analisis secara komprehensif belum dilakukan. Sasaran program ini dalam jangka pendek adalah agar mahasiswa belajar tentang hal-hal yang dapat membantu penelitian seperti menguasi materi manajemen software, dapat menggunakan dan memanfaatkan. Adapun tujuan jangka panjang adalah mendukung fakultas 
untuk menghasilkan lebih banyak tulisan ilmiah oleh mahasiswa dan ikut meningkatkan publikasi yang ada di Fakultas Teknik UGM

b. Kesesuaian program dengan visi dan misi

Visi dan misi tercatat di website perpustakaan dengan url http://lib.ft.ugm.ac.id . Visi Perpustakaan FT UGM adalah:

"Menjadi perpustakaan yang representative untuk menopang kegiatan akademik keteknikan dan sebagai tempat rekreasi serta pengembangan diri civitas akademika FT UGM"

Misi Perpustakaan FT UGM adalah: 1. Menyediakan tempat yang nyaman untuk belajar bagi civitas akademika FT UGM, 2. Meningkatkan kualitas SDM perpustakaan. 3. Menyediakan koleksi teknik, dan non teknik untuk pengembangan diri 4. Mengembangkan layanan kreatif untuk mahasiswa. 5. Bekerjasama dengan berbagai pihak dalam rangka pengembangan perpustakaan. 6. Perancangan digital library dan implementasi digital library dalam berbagai bentuknya.

Data dari hasil wawancara dan observasi, kegiatan pendidikan pemakai sudah sesuai dengan misi dan misi perpustakaan yaitu untuk menopang kegiatan akademik di Fakultas Teknik UGM. Pada pelaksanannya tidak hanya mahasiswa Fakultas Teknik UGM, tetapi ada mahasiswa dari luar Fakultas dipesilakan yang berkegiatan di sana.

c. Kerjasama dengan pihak lain

Penyelenggaraan program ini bekerjasama dengan stakeholder yang ada di Fakultas Teknik UGM. Bentuk kerjasama ada dua macam yaitu pertama, dukungan sarana dan prasarana. Dukungan ini berupa penyediaaan barang dan alat untuk training dan pembelajaran. Kerjasama dengan administrasi Fakultas untuk pengadaan alat dan bahan sesuai dengan spesifikasi yang diusulkan oleh Perpustakaan. Dukungan lain adalah fakultas memberikan kesempatan bagi pustakawan selaku tutor kegiatan untuk mengembangkan diri dengan tujuan meningkatkan kompetensi melalui pelatihan TOT (Training of Trainer) dan workshop. Kedua, dukungan tutor. Tutor dari program ini tidak hanya pustakawan Perpustakaan FT UGM, tetapi juga bekerjasama dengan pihak lain sesuai dengan training yang dilaksanakan. Training dengan tema-tema khusus kerjasama dengan tutor dan pengampu sesuai dengan bidangnya. Kegiatan diskusi pakar juga mendatangkan pengampu sesuai dengan tema diskusi. Kerjasama yang mendukung program ini salah satunya yaitu Layanan MIC (Microsoft Innovation Center). Layanan yang diberikan adalah: Software gratis dalam 
MSDNAA, termasuk lisensi Microsoft windows (khusus civitas akademika Fakultas Teknik UGM), Microsoft online 365 dan email (khusus civitas akademika Fakultas Teknik UGM) dan Microsoft for education bagi guru/pegiat pendidikan.

\section{Evaluasi Input}

Evaluasi input ini membantu memformulasikan kebijakan bagaimana hal ini seharusnya dilakukan. Komponen pada evaluasi input meliputi SDM, anggaran, ketersediaan sarana dan prasarana

a. Ketersediaan sarana dan prasarana

Ketersediaan ruang dan sarana tersebut sudah cukup memadai untuk digunakan sebagai tempat training dan diskusi pakar. Hal ini terbukti dari hasil wawancara dengan responden semua menyatakan puas terhadap sarana dan prasarana yang disediakan oleh perpustakaan (lampiran transkrip wawancara responden).

Fakta lain tentang ruangan dan fasilitas yang memadai terlihat pada foto berikut ini:

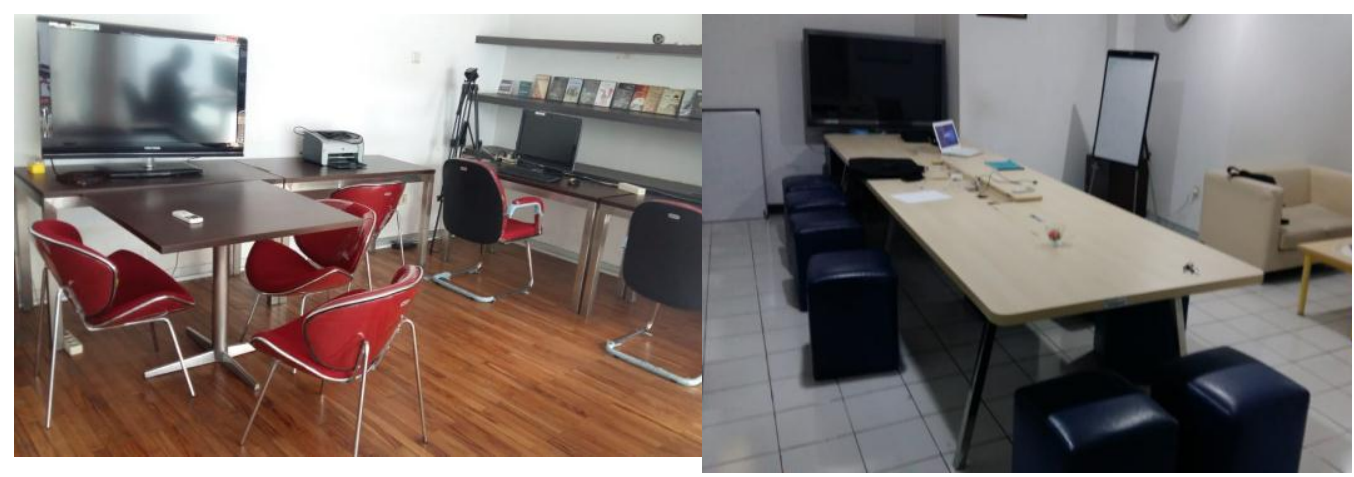

Gambar 4. Ruang Pelatihan di Lantai 1 di Ruang ETD

Gambar 5. Ruang Pelatihan Lantai 1 


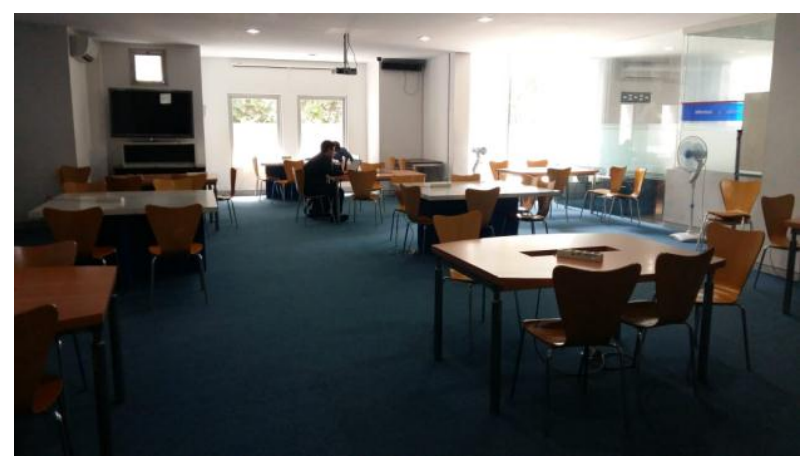

Gambar 6. Ruang Belajar Lantai 1

Gambar tersebut di atas menunjukkan ruangan yang memadai untuk belajar dan berkegiatan. Kenyamanan ruang merupakan salah satu faktor informasi yang diberikan dapat terserap dengan baik.

b. Sumber Daya Manusia

Sumber daya manusia (SDM) yang dimaksud adalah kompetensi dari tutor/mentor pada pendidikan pemakai perpustakaan. Mentor untuk pendidikan pemakai perpustakaan ada dua macam yaitu pustakawan dan non pustakawan. Untuk non pustakawan bekerjasama dengan dosen dan mahasiswa sesuai dengan bidang ilmunya. Kualifikasi mentor adalah sebagai berikut:

Tabel 3. Kualifikasi Mentor Pendidikan Pemakai

\begin{tabular}{|c|c|c|c|c|}
\hline No & Nama & Profesi & Pendidikan & Trainer \\
\hline 1. & Purwoko, SIP, MA & Pustakawan & $\begin{array}{l}\text { S2 Magister Ilmu } \\
\text { Perpustakaan }\end{array}$ & $\begin{array}{ll}- & \text { Mendeley } \\
- & \text { Zotero } \\
- & \text { Scopus untuk riset } \\
- & \text { Mind Map } \\
\text { - } & \text { Visualisasi data } \\
- & \text { Latex } \\
- & \text { MS Word / Libre Office } \\
- & \text { RSS \& Search Alert }\end{array}$ \\
\hline 2. & Bagus Wijaya, SIP & Pustakawan & $\begin{array}{l}\text { S1 Ilmu } \\
\text { Perpustakaan }\end{array}$ & $\begin{array}{ll}- & \text { Mendelay } \\
- & \text { Zotero } \\
- & \text { MS Word }\end{array}$ \\
\hline
\end{tabular}


3. Ir. Subagyo, Ph.D Dosen

4. Dr. Eng. Sunu Dosen

Wibirama, ST,

MEng

5. I Made Andi

Arsana, ST, B.Eng,

Ph.D

Dosen

6. Muslim Mahardika, Dosen ST, M.Eng, Ph.D

7. Prof. Ir. Achmad Djunaedi, MURP., Ph.D

8. Ir. Lukito Edi N, Dosen M.Sc, Ph.D

9. Sarju Winardi, ST, Dosen MT

10. Dr. Ir. I Wayan Dosen Warmada

11. Nugroho Iman S, Dosen Ph.D

12. MIC ( Microsoft Innovation Center)

13. Mahasiswa

Mahasiswa

Staf MIC
- $\quad$ Mind Map

Teknik Mesin dan Plagiarisme Industri

Teknik Elektro _ - Paraphrasa

dan Informatika

- How to write a better thesis

Teknik Geodesi

- Presentasi ilmiah

- Kiat mendapatkan beasiswa luar negri

- Bedah buku

Teknik Mesin dan Jurnal Internasional Industri

Teknik Arsitektur Metodologi Penelitian dan Perencanaan

Teknik Elektro dan Informatika

Kiat mendapatkan beasiswa luar negri

Teknik Geologi Literature review

Teknik Geologi Latex

Teknik Geologi Berbagi cerita ke antartika

- MS Word

- MS Exel

- Visio

- Office Sway

- $\quad$ Software R

- SPSS

- $\quad$ Rapid Miner

- $\quad$ Yed

- Gnuplot

- Latex

- $\quad$ Libre Office

Sumber: data primer diolah

Data tersebut menunjukkan bahwa SDM yang menjadi pengampu untuk pendidikan pemakai sudah memenuhi kriteria kompetensi yang dibutuhkan. Kegiatan pendidikan perpustakaan model training dan diskusi 
pakar adalah termasuk kegiatan literasi informasi. Hal ini sesuai dengan definisi literasi informasi yang dikeluarkan oleh Standar Kompetensi Kerja bidang Perpustakaan menyebutkan tentang literasi informasi yaitu :

"Literasi informasi mencakup pula kegiatan untuk meningkatkan kemampuan pemustaka yang dibutuhkan dalam mengevaluasi secara kritis cakupan (isi) informasi dan menggunakannya secara efektif, sesuai etika informasi serta memahami infrastruktur informasi yang mendasari pengiriman informasi mencakup hubungan dan pengaruh sosial, politik dan budaya"

Kompetensi yang dibutuhkan untuk kegiatan ini adalah: mengumpulkan, menganalisis dan mengorganisasikan informasim mengkomunikasikan informasi dan ide-ide, merencanakan dan mengorganisasikan kegiatan, bekerjasama dengan orang lain dan kelompok, menggunakan gagasan secara matematis dan teknis, memecahkan masalah, menggunakan teknologi

c. Pengalaman tutor

Kegiatan ini telah berjalan selama 3 (tiga) tahun yaitu dari 2015 hingga sekarang. Materi yang diberikan bervariasi disesuaikan dengan permintaan pemakai. Data tabel 11 menunjukkan trainer yang memberikan pembelajaran sangat berkompeten sesuai dengan bidang ilmunya. Materi training ada yang berasal dari usulan mahasiswa, dan mereka menjadi tutor untuk mahasiswa lainnya (data tabel 11). Kegiatan lain di luar Fakultas Teknik UGM pernah dilaksanakan. Mahasiswa tersebut pernah mengikuti kegiatan training, kemudian memberikan usulan kegiatan dan diakomodir oleh perpustakaan. Informasi dari responden menunjukkan fakta bahwa perpustakaan menerima usulan dari mahasiswa dan membantu untuk tutor yang kompeten di bidangnya.

d. Karakteristik peserta

Tujuan utama dari pendidikan pemakai di Perpustakaan FT UGM adalah untuk membantu proses akademik mahasiswa Fakultas Teknik UGM. Mahasiswa Fakultas Teknik yang berasal dari 8 Departemen adalah mahasiswa yang sehari-hari belajar tentang ilmu teknik atau eksakta maka perpustakaan menyesuaikan dengan kebutuhan mahsiswa. Training yang dilaksanakan ada beberapa khusus bidang teknik/eksakta yaitu: Latex, Visual Data dan Visio. Hasil penelitian juga menunjukkan peserta pelatihan tidak hanya dari Fakultas Teknik UGM tetapi ada beberapa berasal dari fakultas 
lain dan universitas lain. Untuk itu Perpustakaan FT juga membuat pendidikan pemakai yang sifatnya umum selain non-teknik bisa mengikuti.

e. Perencanaan program

Program pendidikan pemakai ini merupakan ide dari Kepala Perpustakaan sebagai hasil observasi selama mengelola perpustakaan FT UGM. Setiap tahun program ini masuk dalam rencana program perpustakaan. Analisis kebutuhan oleh perpustakaan secara komprehensif dalam bentuk asesmen tidak ada. Analisis kebutuhan dilakukan secara kultur membaur dengan mahasiswa, mengamati dan melakukan wawancara hingga diputuskan untuk memberikan training dan pembelajaran di perpustakaan. Analisis kebutuhan program perlu dilakukan agar bisa tepat sesuai sasaran secara efektif dan efisien. Pendaftaran peserta dilakukan melalui media Whatsapp, line dan telegram. Setiap kegiatan yang terlaksana di bentuk grup secara ad hock untuk sementara sebagai informasi dan komunikasi. Materi program yang sudah terlaksana beberpa bisa diunduh melalui website perpustakaan dalam bentuk soft file.

\section{f. Anggaran program}

Program ini merupakan kegiatan rutin di Perpustakaan FT UGM yang gratis untuk semua peserta baik dari Fakultas Teknik UGM maupun dari luar. Anggaran yang dibutuhkan untuk kegiatan ini berasal dari RKAT Fakultas Teknik UGM. Data peruntukkan anggaran tersebut menunjukkan bahwa Fakultas mendukung pelaksanaan kegiatan ini.

\section{Evaluasi Process}

Evaluasi process bermanfaat dalam memantau pelaksanaan program. Kegiatan yang dilakukan akan mempengaruhi out put yang dihasilkan. Evaluasi proses untuk melihat kesesuaian antara program yang terlaksana dengan perencanaan dan tujuan dari program.

a. Jadwal pelaksanaan

Tabel 7 menunjukkan data bahwa kegiatan belum terjadwal dengan pasti. Kegiatan dilakukan sesuai permintaan dan kebutuhan mahasiswa. Jadwal kegiatan diinformasikan lewat media twitter, whatsapp, line dan website perpustakaan. Responden dari pihak mahasiswa mengusulkan adanya jadwal yang pasti untuk kegiatan agar bisa mengikuti menyesuaikan waktu. Berikut adalah petikan wawancara dengan responden:

"Wah ini kurang jelas karena perpustakaan memberikan info bukan di web tapi di grup. Tapi jelasnya tiba-tiba saya jadi bingung mau 
atur jadwal bagaimana. Jadi kalau bisa terschedule bulan itu sudah ada tapi saya cari di webnya kok tidak ketemu ya. Apa saya buta informasi atau tampilannya kurang jelas ke saya.

Tanggapan responden tersebut menunjukkan bahwa pelaksanaan kegiatan berlum terjadwal dengan jelas.

b. Implementasi pelaksanaan program

Program ini telah terlaksana selama 3 tahun sejak 2015 hingga sekarang. Berikut adalah grafik pelaksanaan kegiatan dari tahun 20152017(Tabel 7):

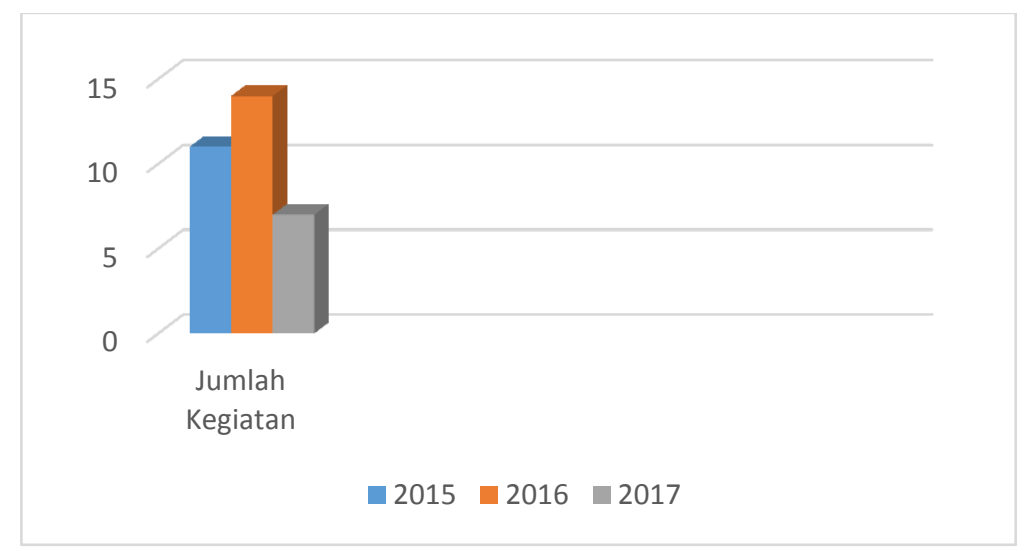

Gambar 7. Jumlah Kegiatan

Kegiatan pendidikan pemakai sebanyak 20 kegiatan. Grafik 1 menunjukkan bahwa kegiatan terbanyak ada di tahun 2016, kemudian menurun di tahun 2017. Salah satu faktor penyebabnya menurut informasi dari tim manajemen adalah jadwal tutor yang bersamaan dengan kegiatan lain. Penyebab lainya adalah kegiatan di tahun 2017 dari sisi jumlah berkurang, tetapi dari jenis kegiatan bertambah. Hal ini menyebabkan jumlah peserta secara keseluruhan juga mengalami penurunan di tahun 2017 seperti terlihat pada grafik berikut ini: 


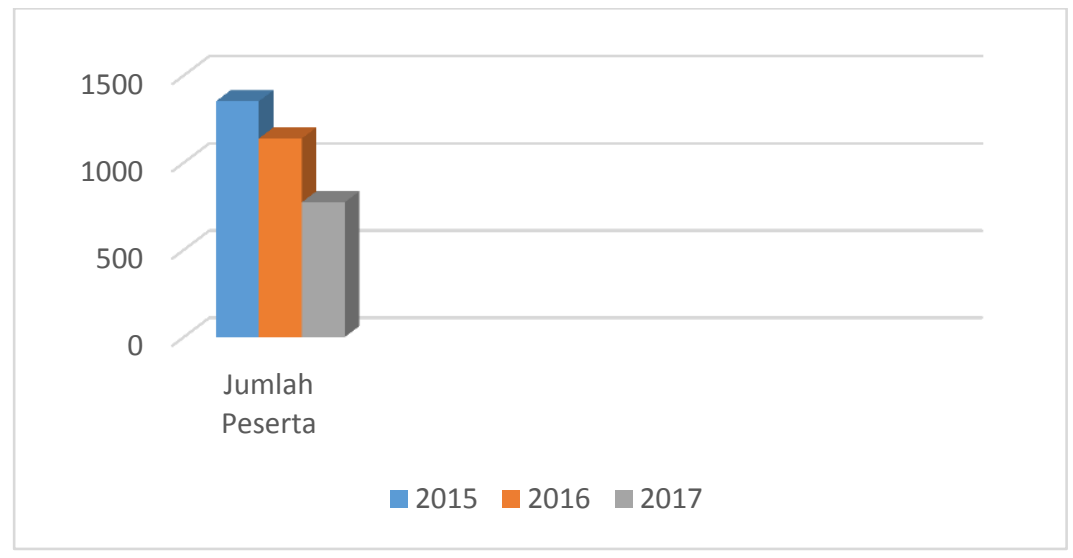

Gambar 8. Jumlah Peserta

Jumlah peserta terbanyak dari kegiatan ini adalah di tahun 2015 saat pertama kali program diluncurkan. Hasil dari penelitian menunjukkan penyebabnya adalah karena sebelum tahun 2015 tidak ada kegiatan training dan pelatihan maka mahasiswa banyak yang mengikuti. Di tahun 2016 mahasiswa mengikuti kegiatan yang belum pernah dilakukan di tahun sebelumnya. Sedangkan di tahun 2017 penyebabnya adalah jumlah kegiatan yang ditawarkan ke mahasiswa tidak sebanyak tahun-tahun sebelumnya, tetapi variasi kegiatan bertambah. Tambahan kegiatan ada yang berasal dari usulan mahasiswa.

\section{c. Kesanggupan Pelaksanaan Program}

Program bisa terlaksana apabila ada person in charge atau orang yang bertindak mengurus kegiatan dari awal sampai akhir. Kegiatan pendidikan pemakai di Perpustakaan FT UGM ada 3 unsur yaitu : staf administrasi, tutor dan Peserta. Staf administrasi bertugas melakukan pendaftaran, mengatur jadwal, menyiapkan sarana pembelajaran dan memastikan kegiatan berjalan sesuai rencana. Tutor bertugas memberikan materi sesuai dengan tema training dan sesuai dengan jadwal pelatihan. Peserta datang sesuai dengan jadwal yang telah disediakan. Apabila salah satu unsur tidak bisa memenuhi tugasnya maka kegiatan tidak bisa dilaksanakan dengan baik. Kegiatan tahun 2017 seperti telah di uraikan di atas, menjadi kegiatan yang paling sedikit dari sisi jumlah. Perpustakaan bisa mengatasi dengan memberikan tawaran kepada pustakawan di Departemen untuk ikut memberikan pelatihan yang dilakukan. Data pustakawan di Departemen adalah sebagai berikut:

Tabel 4. Data Pustakawan Departemen

\begin{tabular}{|c|c|c|}
\hline No & Perpustakaan & Jumlah \\
\hline
\end{tabular}


Tik Ilmeu, VOL.3, NO.1, 2019|59

\begin{tabular}{llll}
\hline \multicolumn{3}{c}{ Departemen } & \multicolumn{2}{c}{ Pustakawan } \\
\hline 1. & Teknik Kimia & - & \\
2. & $\begin{array}{l}\text { Teknik Mesin dan } \\
\text { Industri }\end{array}$ & 1 & Sarjana \\
3. & $\begin{array}{l}\text { Teknik Arsitektur } \\
\text { dan Perencanaan }\end{array}$ & 1 & Diploma \\
4. & Teknik Geodesi & - & - \\
5. & Teknik Geologi & 1 & Sarjana \\
6. & Teknik Sipil dan & - & - \\
Lingkungan & & - \\
7. & Teknik Elektro dan & - & \\
& $\begin{array}{l}\text { Teknologi } \\
\text { Informasi }\end{array}$ & & \\
8. Teknik Nuklir dan & - & \\
& Teknik Fisika & & \\
\hline
\end{tabular}

Sumber: data primer diolah

Jumlah total pustakawan Departemen dan Fakultas ada 7 orang. Pemetaan pustakawan di fakultas bisa diterapkan untuk program ini agar bisa berjalan secara konsisten tiap tahun.

d. Strategi Pelaksanaan Program

Program yang dilaksanakan memiliki sasaran jangka pendek dan jangka panjang. Tidak ada dokumen tertulis untuk sasaran program ini. Informasi tentang sasaran program didapatkan dari hasil dari wawancara kepada tim manajemen. Kesimpulan berdasarkan informasi dari reponden, sasaran program ini adalah sasaran jangka pendek yaitu memberikan bekal ketrampilan bagi mahasiswa hingga menguasai materi yang diberikan. Sasaran jangka panjan, yaitu mendukung fakultas untuk meningkatkan tulisan ilmiah dan publikasi dengan memberikan pelatihan yang sesuai.

Strategi yang dilaksanakan untuk mencapai sasaran program adalah dengan mengadakan pelatihan sesuai dengan kebutuhan mahasiswa. Kegiatan yang dilakukan tidak selalu berkelompok, tetapi ada yang sifatnya privat atau one on one training difasilitasi oleh perpustakaan seperti kegiatan Matlab. Strategi lain yaitu melalui komunikasi yang dilakukan dengan peserta. Perpustakaan FT UGM membuat grup-grup dengan media Whatsapp, Line dan telegam. Informasi yang dibagikan di grup adalah tentang jadwal kegiatan, materi dan tanya jawab dengan tutor. Selain itu, mahasiswa 
dipersilakan datang ke perpustakaan apabila membutuhkan informasi lebih lanjut tentang materi yang telah diajarkan.

\section{Evaluasi Product}

Evaluasi product bertujuan untuk memberikan masukan terkait keputusan selanjutnya baik mengenai hasil yang telah dicapai maupun selama proses kegiatan tersebut berjalan.

a. Penilaian

Hasil penilaian terhadap peserta pelatihan dilakukan dengan memberikan sertifikat telah mengikuti program. Pada pelaksanaanya sertifikat ini diberikan sesuai dengan permintaan dari peserta.

b. Keberhasilan program

Keberhasilan program dilihat dari manfaat yang dirasakan oleh mahasiswa dan tercapai tujuan pogram. Informasi tentang capaian tujuan program merupakan hasil wawancara dengan tim manajemen. Tujuan dari kegiatan ini adalah untuk membantu proses akademik mahasiswa di Fakultas Teknik UGM. Hasil dari kegiatan adalah berupa pelatihan yang sudah terlaksana. Indikator keberhasilan apabila dilihat dari jumlah publikasi dan penelitian belum ada penelitian tentang tentang aku. Indikator keberhasilan dari penyampaian materi sudah tercapai karena dari materi yang direncakan sebanyak $90 \%$ telah dilaksanakan. Indikator keberhasilan dari jumlah peserta sudah tercapai karena lebih dari separo mahasiswa fakultas teknik mengikuti pelatihan, hal ini dilihat dari jumlah total peserta pelatihan per tahun 2015 hingga 2017. Hasil wawancara kepada responden adalah manfaat dari program ini membantu keberhasilan studi dan tugas akhir dari mahasiswa.

c. Kebutuhan peserta

Keberhasilan suatu program salah satunya yaitu kebutuhan peserta sudah terpenuhi. Informasi tentang kebutuhan mahasiswa belum ada analisis khusus tentang kebutuhan. Hal yang telah dilakukan adalah perpustakaan mengakomodir dan memfasilitasi usulan mahasiswa tentang kegiatan tertentu. Hasil wawancara dengan responden mahasiswa program terjadwal dengan baik dan beberapa program yang telah terlaksana dilakukan kembali seperti SPSS. 
Tik Ilmeu, VOL.3, NO.1, 2019|61

\section{Analisis Implementasi Kegiatan Pendidikan Pemakai di Perpustakaan Fakultas Teknik UGM}

Perubahan tren layanan perpustakaan yang tadinya hanya bersifat peminjaman dan pengembalian buku, berkembang menjadi layanan user training program. Artinya, program pendidikan pemakai merupakan bagian dari layanan perpustakaan sesuai dengan kebutuhan pemustaka. Perpustakaan perguruan tinggi dapat mengaplikasikan proram pendidikan pemakai sesuai dengan jenjang level mahasiswa. Oleh karena itu, implementasi pendidikan pemakai di perpustakaan perguruan tinggi merupakan hasil kolaborasi antara pustakawan, staf akademik, bagian teknologi informasi dan mahasiswa agar bisa tepat sasaran. Hal ini dapat tercapai apabila mahasiswa keleluasaan untuk mengembangkan segenap potensinya, mengeksplorasi bidang ilmu yang diminati, serta mencapai kompetensinya melalui proses pembelajaran aktif dan mandiri. Peran dari perpustakaan adalah menyediakan fasilitas dan sumber belajar yang bisa dimanfaatkan oleh mahasiswa untuk mendukung studinya.

Perpustakaan FT UGM menggunakan pendekatan yang humanis (humanis approach) sebagai metode pembelajaran. Kegiatan yang dilakukan merupakan hasil berdialog dengan mahasiswa, berbaur secara kultural sehingga bisa memberikan solusi untuk pembelajaran mahasiswa. Peserta mengendalikan dan mengontrol apa dan bagaimana mereka belajar, memilih yang paling mereka pahami dan kemudian mengembangkan sesuai dengan pilihan mereka. Hal ini bisa dilihat beberapa kegiatan merupakan usulan dari mahasiswa yang diwujudkan oleh perpustakaan. Implementasi pendidikan pemakai di perpustakaan Fakultas Teknik UGM meliputi 3 hal yaitu, Level pertama atau level dasar berupa materi yang diberikan adalah pencarian infromasi dasar, manajemen sitasi, penggunaan MS Office, Mind Map dan Soft Skill Training, Prezy, metodologi penelitian. Level kedua, diberikan pada mahasiswa sesuai dengan jurusan masing-masing. Materi yang diberikan adalah sesuai permintaan mahasiswa. Yang sudah terlaksana adalah Latex, SWAY, Gnuplot, LyX, Autocad. Level ketiga, literature search training, adalah pemberian pendidikan pemakai dengan lebih menekankan pada praktek pencarian literatur untuk penelitian, hal ini tepat untuk persiapan tugas akhir/penelitian (tesis, skripsi, desertasi). Materi yang diberikan adalah scoupus untuk riset, paraphrase, jurnal internasional, literatur review, jurnal internasional dan plagiarismem. Mahasiswa tidak diwajibkan mengikuti seluruh level. Informasi yang didapat dari hasil wawancara dengan responden adalah mahasiswa bisa memilih kegiatan yang sesuai dengan kebutuhan dan minatnya. 


\section{Analisis Faktor Pendukung Kegiatan Pendidikan Pemakai di Perpustakaan Fakultas Teknik UGM}

Proses analisis yang digunakan dalam penelitian ini adalah hasil evaluasi dengan metode CIPP yang telah diuraikan di atas. Hasil evaluasi menunjukkan beberapa faktor pendukung untuk kegiatan ini. Kompetensi SDM, SDM yang bertugas memberikan pembelajaran dalam hal ini tutor sangat berkompeten di bidangnya. Pustakawan yang memberikan tutorial rata-rata telah bekerja di Perpustakaan Faultas Teknik UGM lebih dari 5 tahun, jadi pemahaman terhadap karakteristik mahasiswa dan literatur bidang teknik sudah menguasai. Latar belakang pendidikan pustakawan sebagai pengampu cukup berkompeten baik pendidikan formal maupun pelatihan dan workshop yang diikuti. Tutor untuk kegiatan dengan tema tertentu dipilih sesuai dengan bidang kepakaran, baik dari Fakultas Teknik UGM maupun luar Fakultas Teknik UGM. Dosen pengampu 95\% adalah tingkat doktoral, atau S3.

Perpustakaan menyediakan sarana komunikasi lewat media yang bisa diikuti oleh mahasiswa. Ada berbagai pilihan media yaitu whatsapp, telegram, line, twitter dan instagram. Hal ini memudahkan bagi mahasiswa untuk mendaptkan informasi yang dibutuhkan. Selain itu meraka bisa melakukan tanya jawab di forum grup terkait materi yang pelatihan. Komunikasi langsung secara face to face juga difasilitasi oleh perpustakaan dengan mempersilakan mahasiswa yang mengalami kesulitan selelah mengikut pelatihan, bisa datang dan berkonsultasi di perpustakaan.

Kerjasama dengan manajemen Fakultas dan stakeholder terjalin dengan baik. Fakultas memberikan dukungan berupa sarana dan prasarana pengadaan barang dan peralatan yang dibutuhkan untuk program ini. Terbukti dari fasilitas yang ada mengalami pertambahan dari tahun ke tahun baik dari sisi jumlah maupun kualitasnya. Dukungan lain yaitu memberikan kesempatan bagi pustakawan untuk pengembangan diri dengan tujuan meningkatkan kompetensi yaitu dengan memberikan ijin dan membiayai pelatihan yang dibutuhkan.

Sarana dan prasarana untuk pelatihan sudah memadai, hal ini terbukti dari hasil wawancara dengan responden semua menyatakan puas terhadap sarana dan prasaranan. Fakultas sebagai institusi induk mendukung fasilitas untuk pelaksanaan kegiatan ini dengan mengadaan barang dan peralatan untuk kegiatan sesuai usulan dari Perpustakaan. Fasilitas jaringan dan internet tersedia dengan lancar. Mahasiswa diberi hak akses menggunakan hotspot UGM dengan akun masing-masing. Pembagian zona ruang 
merupakan salah satu faktor pendukung kenyamanan mahasiswa, karena mahasiswa bisa memilih ruangan untuk belajar secara privat atau berkelompok sesuai dengan tujuan masing-masing.

\section{Analisis Faktor Penghambat Kegiatan Pendidikan Pemakai di Perpustakaan Fakultas Teknik UGM}

Proses analisis yang digunakan faktor penghambat kegiatan dengan evaluasi metode CIPP yang telah diuraikan di atas. Hasil evaluasi menunjukkan beberapa faktor penghambat untuk kegiatan ini. Hasil evaluasi tentang jadwal pelatihan menunjukkan belum ada jadwal yang pasti atau rancangan program per tahun dari kegiatan ini. Informasi kegiatan dilakukan dalam batas waktu 2 minggu sebelum kegiatan berlangsung. Hal ini bisa menjadi hambatan bagi mahasiswa yang membutuhkan tetapi tidak sesuai dengan waktunya. Usulan mahasiswa agar ada jadwal kegiatan pasti per bulan atau bahkan bisa per minggu perlu diwujudkan agar mahasiswa bisa mengikuti sesuai dengan kebutuhannya. Informasi jadwal kegiatan juga bisa disajikan di website perpustakaan dengan lebih jelas dan informatif.

Person in charge ini adalah penanggungjawab kegiatan. Pelaksanaan kegiatan tergantung dari kepala perpustakaan dan tutor yang melaksanakan. Hasil penelitian yang mengungkapkan fakta kegiatan dari 2015-2017 ada beberapa kegiatan yang tidak dilakukan secara kontinyu. Hal ini bisa diatasi dengan kolaborasi dengan pustakawan di seluruh departemen di fakultas untuk bisa mendukung kegiatan ini.

Hasil observasi menemukan fakta bahwa analisis kebutuhan kegiatan belum dilakukan oleh perpustakaan. Analisis ini diperlukan agar dapat mengidentifikasi kebutuhan mahasiswa secara real, sehingga program yang dilaksanakan tepat sasaran sesuai dengan tujuan yang telah ditetapkan. Asesmen tentang keberhasilan program juga perlu dilakukan dengan menganalisis korelasi pendidikan pemakai perpustakaan dengan keberhasilan studi dan penelitian mahasiswa. Hasil asesmen ini untuk menunjukkan pengaruh program ini untuk mendukung proses akademik mahasiswa. Perpustakaan tidak memiliki kebijakan tertulis untuk kegiatan ini. Kebijakan tertulis dapat berupa Surat Keputusan sebagai pedoman legal formal kegiatan tersebut. Hal ini penting karena dengan adanya kebijakan tertulis terdapat aturan yang jelas terhadap kegiatan tersebut. 


\section{KESIMPULAN}

Penelitian ini bertujuan untuk meneliti mengetahui implementasi pendidikan pemakai di Perpustakaan Fakultas Teknik UGM. Berdasarkan uraian hasil penelitian yang telah dibahas di bab sebelumnya maka bisa diambil kesimpulan yaitu pendidikan pemakai di perpustakaan meliputi 3 level. Level pertama atau level dasar diberikan pengenalan perpustakaan dapat diaplikasikan untuk mereka yang pertama kali memanfaatkan perpustakaan., level kedua, diberikan pada mahasiswa sesuai dengan jurusan masing-masing. Level ketiga, literature search training, adalah pemberian pendidikan pemakai dengan lebih menekankan pada praktek pencarian literatur untuk penelitian, hal ini tepat untuk persiapan tugas akhir/penelitian (tesis, skripsi, desertasi). Faktor-faktor yang mendukung pelaksanaan program adalah kompetensi Sumber Daya Manuasi, komunikasi, sarana dan prasana yang memadai, dan kerjasama yang baik dengan stakeholder. Faktorfaktor yang menghambat program adalah jadwal kegiatan yang belum rutin, penanggung jawab program belum bisa didelegasikan kepada orang lain, belum ada analisis kebutuhan mahasiswa, dan belum ada kebijakan tertulis tentang program ini

Saran dalam penelitian evaluasi CIPP adalah berupa rekomendasi kebijakan kepada perpustakaan yaitu membuat perencanaan program dengan lebih terstruktur dari jadwal, materi dan jenis kegiatan. Membuat kebijakan tertulis yang informatif. Membuat program dalam bentuk paket kegiatan sehingga mahasiswa bisa memilik paket kegiatan yang sesuai dengan kebutuhannya. Jadi mahasiswa akan tertarik mengikuti kegiatan per paket sehingga bisa mendapatkan ilmu secara komplit sesuai dengan paket yang dipilih.

\section{DAFTAR RUJUKAN}

Arikunto, Suharsimi. 1993. Manajemen Penelitian. Jakarta: PT Raja Grafindo Perkasa.

Australian Library Association. 2012. The Role Of Libraries and Library Adn Information Profesionals. Australian Library and Informastion Association. https://www.alia.org.au/information-and-resources/aboutsector.

Chen, Kuan-nien, and Pei-chun Lin. 2011. Information Literacy in University Library User Education. Aslib Proceedings 63(4): 399-418. http://www.emeraldinsight.com/doi/abs/10.1108/00012531111148967

Downard, Karen. 1992. User Education in Academic Libraries. Library Management 13(3). 
Tik Ilmeu, VOL.3, NO.1, 2019|65

http://search.proquest.com.ezproxy.ugm.ac.id/docview/198855982?acco untid=13771.

Al Hamidy, Yusuf Dzul Ikram, and Heriyanto Heriyanto. 2012. Kemampuan

Literasi Informasi Mahasiswa Pada Layanan American Corner Di UPT

Perpustakaan IAIN Walisongo Semarang Menurut Association of

College and Research Libraries. Jurnal Ilmu Perpustakaan 1(1): 1-9.

Harker, Emily. 2009. Learning about Learning. Health Information \&

Libraries Journal 26(2): 156-60.

Harsono. 2008. Student Center Learning Di Perguruan Tinggi. Jurnal

Pendidikan Kedokteran dan Profesi Kesehatan Indonesia 3(1): 4-8.

Klain-Gabbay, Liat, and Snunith Shoham. 2016. Scholarly Communication

and Academic Librarians. Library \& Information Science Research

38(2): 170-79.

Lewin, Heather S., and Sarah M. Passonneau. 2012. An Analysis of

Academic Research Libraries Assessment Data: A Look at Professional

Models and Benchmarking Data. The Journal of Academic

Librarianship 38(2): 85-93.

http://linkinghub.elsevier.com/retrieve/pii/S0099133312000171

(September 10, 2014).

Sarjono. 2013. Efektivitas Pendidikan Pemakai Di Universitas Gadjah Mada.

Berkala Ilmu Perpustakaan dan Informasi 9(12): 1-7.

Sugiyono. 2008. Memahami Penelitian Kualitatif. Bandung: Alfabeta.

Tawaf, Muhammad. 2007. Pendidikan Pemakai (User Education) Dan

Pemanfaatan Perpusakaan (Studi Kasus Di Perpustakaan UIN Suska

Riay." Anida (43): 72-96. 